\title{
Construction audit as a modern instrument of investment and construction process management
}

\author{
Olga Didkovskaya ${ }^{1}$, Olga Mamayeva ${ }^{1}$, and Alexey Bocharov ${ }^{1, *}$ \\ ${ }^{1}$ Samara State Technical University, Institute of Architecture and Civil Engineering, \\ Molodogvardeyskaya str. 194, 443001 Samara, Russia
}

\begin{abstract}
The problem of methodical approaches formation for implementation and use of the construction audit as a new control instrument in investment and construction projects is discussed in this paper. The authors analyzed and generalized the theory and practical experience of construction and technical as well as economic expert assessments concerning capital construction projects. A complex methodological basis of construction audit adapted for Russian legislation conditions and applied to investment and construction projects of various readiness level is also given in this article. The main reasons defining the relevance of the subject are the increasing requirement and lack of methodical support of this expert activity type in construction providing insufficiency conditions of its standard and legal regulation.
\end{abstract}

\section{Introduction}

Today, a range of target investment construction programs confined to important events is realized on a nationwide scale. The audit of realization processes is becoming a perspective activity. In this regard the state undertakes different measures to introduce some control instruments over investment and construction processes. At the same time, the scope of available legitimate tools is limited. Construction audit as expert study is very complex and universal and it includes the examination and control of investment construction projects (capital construction projects) from the legal, construction technical, financial and economic points of view.

Construction audit feature provides control over project execution of each process (including incomplete one) and each division participating in its realization, but techniques (rules, standards, regulations) of the organization of such control can be found neither in modern domestic scientific literature, nor in open resources of the profile companies and professional communities.

\footnotetext{
* Corresponding author: kafedra cen@mail.ru
} 


\section{Methodical Basis and Principles of Construction Audit System Formation}

In practice, in the course of construction complex functioning are (investors, customers, builders) often face the necessity to solve problems connected with the violation of standard investment construction procedure and expert study methods.

A set of such methods can be titled as "construction audit" depending on the purpose, stage, nature of the study and its results.

Construction audit is the synthesis of construction technical, legal and financial economic expert studies carried out for the assessment and optimization process of investment construction implementation projects at any stages. The listed types of research can be carried out separately or all together.

The development of this type of professional activity is relevant for several reasons:

- growing need for internal and external auditor services concerning the realized investment construction projects (first of all, state ones);

- drawbacks in standard and legal regulation of professional area;

- absence of regulations, rules, standards, implementation techniques of construction audit;

- existence of "critical bulk" of projects (capital construction projects) which are potentially an audit subject.

The analysis of standard and legal base showed that the construction audit as a type of professional activity is subjected to legal co - regulation of urban-planning, investment and expert activity. The construction audit provision in the present legal boundaries is closest to provisions of the following documents:

Clause 53 of the Urban-Planning Code of the Russian Federation and relevant by laws regarding the organization and implementation of construction control procedure;

federal law of 31.05.2001 No. 73-FL "About state judicial and expert activity in the Russian Federation" regarding procedures of judicial construction technical expert studies;

resolutions of the Government of the Russian Federation of 30.04.2013 No. 382 "About carrying out of public technological and price audit of large investment projects with the state participation and about the modification of some acts of the Government of the Russian Federation" regarding large investment projects audit at predesign and design stages.

At the same time, special legislative regulation of construction audit as universal system is absent.

Methodical support development of construction audit needs to be carried out depending on investment construction process stages (Table 1).

Table 1. Types of expert studies at various stages of investment construction process.

\begin{tabular}{|c|c|c|c|}
\hline Pre -design stage & Design stage & Construction & $\begin{array}{c}\text { Setting into } \\
\text { operation }\end{array}$ \\
\hline $\begin{array}{c}\text { Technical economic } \\
\text { reasoning. } \\
\begin{array}{c}\text { Technological and } \\
\text { price audit }\end{array}\end{array}$ & $\begin{array}{c}\text { Project } \\
\text { documentation } \\
\text { expert study. Cost } \\
\text { expert study }\end{array}$ & $\begin{array}{c}\text { Construction technical expert } \\
\text { studies. Construction control. } \\
\text { Incomplete construction } \\
\text { assessment. }\end{array}$ & $\begin{array}{c}\text { Actual expenditure } \\
\text { control. Budget funds } \\
\text { expenditure control. }\end{array}$ \\
\hline \multicolumn{2}{|c|}{ Construction audit } \\
\hline
\end{tabular}

Use of construction audit instruments allows to reduce or to avoid technological and economic hazards of investment construction decisions concerning incomplete construction objects. Condition creation task of construction audit implementation is extremely important. 
Thus, audit should be divided into some directions depending on subjects types of investment construction activity: for an individual builder - technical and financial control (today this niche is occupied by construction and technical experts); for the state and municipal builders the formation of normative legal acts of construction audit is necessary taking into account the level and the size of the budget.

To give this institute power is necessary for:

- investment potential assessments;

- credit investments involvement for construction objects;

- controversial issues solutions between subjects of investment and construction activity;

- control over possible unreliable accounting documents;

- prevention of inappropriate use of monetary funds;

- exclusion of unplanned delay time;

- protection against unplanned actions;

- necessity of wear research.

\section{Construction Audit Perspectives}

Researches for the current investment construction projects and objects of incomplete construction are the most demanded and at the same time least methodically developed field of construction audit. Approaches to construction audit conducting in such cases have to be provided in the complex methodical documents on construction audit.

The generalized scheme of construction audit of the investment and construction project can be submitted according to the following expert actions:

- analysis of initial and permissive documentation;

- analysis of project and detailed documentation;

- analysis of executive documentation;

- adherence to specifications;

- organization and implementation of construction supervision;

- analysis of current construction state;

- analysis of construction deadline;

- assessment of structure, bulk and quality of the performed works;

- analysis of the contract relations;

- analysis of project budget implementation;

- monitoring of target expenditure of capital investments;

- deviations identification of actual indicators of design and their reasons;

- project risks assessment;

- project optimization recommendations, etc.

Methods for the incomplete construction objects include some positions listed above, as well as the delay reasons analysis of construction, an assessment of object completion degree, technical expertise of its state, cost assessment. And the most important thing is recommendations of technical capability, economic suitability and optimum ways of construction completion.

The largest project in Samara region is the stadium construction for the Football World Championship in 2018. It may be considered to be the example of the construction audit. It is known that there is a change of a contractor at the object there. In this connection it is necessary for a customer to receive full and detailed expert information about current construction state with the purpose of taking further management decisions.

The audit study roadmap of the project is shown in Table 2 . 
Table 2. Roadmap of construction audit performance of "Samara Arena" project.

\begin{tabular}{|c|c|c|}
\hline \multirow{9}{*}{$\begin{array}{l}\text { Samara } \\
\text { Arena }\end{array}$} & \multirow{2}{*}{ Project analysis } & Amount and types of work data analysis \\
\hline & & Preliminary cost analysis with deflator index \\
\hline & Contract analysis & Collaboration scheme defining and recommendations \\
\hline & \multirow{5}{*}{$\begin{array}{l}\text { Technical /finance } \\
\text { analysis. } \\
\text { Project supervision } \\
\text { analysis }\end{array}$} & Cost analysis and materials expense norms \\
\hline & & Finance structure analysis \\
\hline & & Condition analysis of work implementation \\
\hline & & Materials and items purchase activity analysis \\
\hline & & $\begin{array}{l}\text { Machine exploitation analysis and machine work at } \\
\text { construction objects }\end{array}$ \\
\hline & & g performed work, developed optimization recommendations \\
\hline
\end{tabular}

\section{Conclusion}

Mechanisms realization of construction audit in the Russian Federation becomes difficult because of the absence of standard legal base, lack of precise understanding of a subject and absence of experts in this branch. In foreign countries the construction audit realization is quite accurate, and unites professional communities (institutes of construction audit and cost control).

The development of legal base and methodological base is the first stage of construction audit effective system as a required element in construction management.

\section{References}

1. Town-planning code of the Russian Federation (federal law of 29.12.2004 No. 190-FZ) (2004)

2. The federal law of 31.05.2001 No. 73-FZ "About the state judicial and expert activity in the Russian Federation" (2004)

3. The resolution of the Government of the Russian Federation of 30.04.2013 No. 382 "About carrying out public technological and price audit of large investment projects with the state participation and about modification of some acts of the Government of the Russian Federation" (2013)

4. O.V. Didkovskaya, O. A. Mamaeva, M. V. Ilyina, Procedia Engineering 153, 131-135 (2016)

5. Yu.P. Sologubov, Traditions and innovations in construction and architecture. Construction: collection of articlesSamara, 308-312 (2016)

6. M.V. Ilyina, Problems and prospects of the development of construction cost engineering system: collection of materials, 107-110 (2015)

7. O.V. Didkovskaya, Cost engineering and examination of real estate: problems and prospects development: Collection of articles, 5-10 (2016)

8. M.A. Konovalova, Cost engineering and examination of real estate: problems and prospects development: Collection of articles, 11-17 (2016)

9. M.V. Ilyina, Cost engineering and examination of real estate: problems and prospects development: Collection of articles, 18-25 (2016)

10. N.S. Belomyttseva, Economic aspects of a construction complex management under modern conditions, 162-165 (2014)

11. O.V. Didkovskaya, Budget and contractual work in construction 11, 23-33 (2014)

12. A.Yu. Bocharov, XXII of the International scientific and practical conference, 165-168 (2013) 